\title{
Integrated Use of Different Sources of Nutrients and Microbes for Improving Quality of Enrich Compost
}

\author{
Kaushal Kumar $^{1 *}$, D.V. Mali ${ }^{1}$, A.O. Shirale ${ }^{2}$, S.D. Jadhao ${ }^{1}$, V.K. Kharche ${ }^{1}$, \\ A.N. Paslawar ${ }^{3}$, Sanjay Kumar ${ }^{4}$ and Shrimohan Meena ${ }^{1}$
}

${ }^{1}$ Department of Soil Science and Agricultural Chemistry, Dr. Panjabrao Deshmukh Krishi

Vidyapeeth, Akola (MS), India

${ }^{2}$ Department of Soil Chemistry and Fertility, Indian Institute of Soil Science, Bhopal, Madhya

Pradesh, India

${ }^{3}$ Department of Agronomy, Dr. Panjabrao Deshmukh Krishi Vidyapeeth, Akola (MS), India

${ }^{4}$ Department of Vegetable Science, CCS Haryana Agricultural University, Hisar, Haryana, India, India

*Corresponding author

\section{A B S T R A C T}

\section{Keywords}

Nitro-phosphosulpho compost, Rock phosphate, Gypsum, Wheat straw and shredded cotton stalk

\section{Article Info}

Accepted:

15 November 2018

Available Online:

10 December 2018
Among the crop residues used for preparation of compost, wheat straw (WS) + urea (1.5 - 4.5 per cent) + rock phosphate (RP) (6 - 12 per cent) + Sulphur (S) (1 to 3\% through gypsum) and shredded cotton stalk (SCS) + urea $(1.5-4.5 \%)+\mathrm{RP}(6-12 \%)$ $+\mathrm{S}$ (1 to $3 \%$ through gypsum) were found equally beneficial in improving the quality of compost. The $\mathrm{pH}$ of compost rises initially and further drop at the maturity of compost. Composting with different sources of nutrient increased the concentration of total nitrogen, phosphorous, Citrate soluble and water soluble phosphorous, potassium, Sulphur and micronutrients concentration with the increased in the levels of gypsum and RP. Organic carbon, microbial respirations and Carbon:Nitrogen ratio $(\mathrm{C}: \mathrm{N})$ decreased with the advancement decomposition progressed. The microbial count (viz. bacteria, fungi and actinomycetes) swiftly rise initially during first 60 to 70 days and thereafter decreased.

\section{Introduction}

Day by day crops production is decreasing due to deterioration of soil health and imbalanced use of fertilizers. One way in which some of the problems associated with the utilization of various organic wastes can be resolved is by composting. Composting is an ancient practice in which organic wastes converted into resources that provide nutrients to crops and enhance the tilth, fertility and productivity of soils. Crop residues are generated in large quantities and constitute an abundant but underutilized source of renewable biomass in agriculture (Parr et al., 1986). The amount of crop residues available in India is estimated to be approximately 620 million tons (Pandey et al., 2009). 
Composts can be further enriched with minerals (rock phosphate and mica) and microbial inoculants (Nitrogen fixers, phosphorus solubilizing bacteria and potassium solubilizing microbes) to enhance the overall quality of these organomineral fertilizers. The application of such bioaugmented nutrient enriched compost in soil leads to a significant increase in the soil fertility status (in terms of microbial biomass, $\mathrm{N}$ and available $\mathrm{P}$ ) enhancing the overall chemical and biological activity of soil. The phosphorus and nitrogen enriched organic residues thus appear as a better alternative than the commercial fertilizer since their low price is not only economical but will also protect the soil from further deterioration and enrich it with nutrients and microbial flora. The application of mineral enriched compost indirectly satisfied the $\mathrm{N}$ and $\mathrm{P}$ needs of plants in nutrient deficient soils. Therefore, recycling of crop residues is an integral part of the strategies of plant nutrient management for sustaining soil health and crop yields.

The compost which was prepared using urea, single super phosphate leads to reduction in $\mathrm{C}: \mathrm{N}$ ratio and increased in other macro and micro nutrients during the decomposition (Manjunatha and Ravi, 2013). Recently, emphasis has been made to the possibility of greater utilization of low cost, indigenously available rock phosphate, gypsum, urea etc. and microorganisms for rapid decomposition. In order to upgrade nutrient content of the compost has been documented by Sibi (2007), Biswas and Narayanasamy (2006), Banta and Dev (2009) and Reddy and Reddy (2002).

Considering high cost of chemical fertilizer and decline in soil health due to imbalance use of chemical fertilizers and emerging multinutrient deficiency, there is urgent need to develop novel technology that can overcome multi-nutrient deficiency (N, P \& S etc.) and enhance soil health. Hence, attempt has been made in present study in order to prepare nutrient enriched compost as alternative option for chemical fertilizers, with the objectives:

1. To assess suitability of different crop residues for preparation of nitro-phosphosulpho compost and

2. To study different physical, chemical and biological parameters during decomposition.

\section{Materials and Methods}

\section{Experimental materials treatments and design}

The experiment comprised of six treatments with three different levels (1, 2 and 3 per cent) of urea, rock phosphate and gypsum in combination with wheat straw (WS) and shredded cotton stalk (SCS) was conducted in completely randomized design with four replications. For each treatment $100 \mathrm{~kg}$ of WS and SCS residues were utilized. The treatment structure constitute of following combinations; $\mathrm{T}_{1}-\mathrm{WS}+$ Urea $1.5 \%+\mathrm{RP} 6 \%+\mathrm{S} 1 \%$ of crop residue; $\mathrm{T}_{2}-\mathrm{WS}+$ Urea $3.0 \%+\mathrm{RP} 9 \%+\mathrm{S} 2$ $\%$ of crop residue; $\mathrm{T}_{3}-\mathrm{WS}+$ Urea $4.5 \%+\mathrm{RP}$ $12 \%+\mathrm{S} 3 \%$ of crop residue; $\mathrm{T}_{4}-\mathrm{SCS}+$ Urea $1.5 \%+\mathrm{RP} 6 \%+\mathrm{S} 1 \%$ of crop residue; $\mathrm{T}_{5}-$ SCS + Urea $3.0 \%+$ RP $9 \%+$ S $2 \%$ of crop residue and $\mathrm{T}_{6}-\mathrm{SCS}+$ Urea $4.5 \%+\mathrm{RP} 12 \%$ $+\mathrm{S} 3 \%$ of crop residue.

The crop residues such as WS, SCS and cow dung slurry were used for preparation of compost. The rock phosphate was brought from Jhabua, Madhya Pradesh and gypsum from local market. The initial nutrient composition of WS, SCS, RP and gypsum was presented in Table 1,2 and 3 respectively.

\section{Experimental methods}

The pit method was employed for the preparation of nitro-phospho-sulpho compost. 
The cotton residues were shredded into small pieces of approximately $2-3 \mathrm{~cm}$ length. The WS and SCS were analyzed in laboratory for initial characterization (Table 1). The crop residues (WS and SCS) were added layer by layer in pits of $1 \times 1 \mathrm{~m}^{3}$ sizes. Thickness of each layer was 3-4 cm treating with cow dung slurry at the rate of $10 \mathrm{kgton}^{-1}$. For enrichment of compost, urea solution (1, 2 and 3 per cent), rock phosphate (RP) (6, 9 and 12 per cent)), sulphur (S) (1, 2 and 3 per cent through gypsum) ware added at total weight of crop residues followed by Phosphorus Soluble Bactria and Trichoderma viride $\left(1 \mathrm{kgton}^{-1}\right)$. The moisture content of compost pits was maintained at 60 to 70 per cent at every seven days interval during the period of experimentation and turnings were given at 10 days interval up to 90 days of decomposition. The experiment was conducted under the shade and pits were covered with polythene to avoid excessive wetting by rains and to avoid sun light. There after 90 days of decomposition, treatment wise heaps were collected at one place and allowed for curing up to 30 days.

\section{Sample collection and analysis}

Three replicates of compost sampled were analyzed. The compost samples from pit collected, dried, ground and sieved by passing through sieve and then used for chemical analysis. Samples were oven dried at $70^{\circ} \mathrm{C}$ and ground to pass through a 20 -mesh sieve size. The representative samples of each treatment were collected after 0, 30, 60, 90 and 120 days of during decomposition for determination of $\mathrm{pH}$ and EC (Jackson, 1973). The organic carbon form compost samples were estimated by taking known quantities of dried samples in a pre-weighed silica crucible. The samples were kept in a muffle furnace at a temperature of $600^{\circ} \mathrm{C}$ for 2 hours. The crucibles were later transferred to desiccators, cooled and immediately weighed to a constant weight (ash weight). The total presence of organic matter was calculated by taking difference of dry weight of samples and ash weight of the sample. Then organic carbon was calculated by dividing the per cent organic matter by the factor 1.724 (Jackson, 1973) as per following equation;

$\%$ Organic Carbon $=100-\%$ Ash $\div 1.724$

Total phosphorus, water-soluble phosphorus and citrate soluble phosphorus (Page et al., 1982), total potassium, sulphur and micronutrients were determined by di-acid extract by using flame photometer (Page et al., 1982), turbidimetric method by di-acid extract using spectrophotometer (Chesnin and Yien, 1950) and micronutrients by atomic absorption spectrophotometer. Microbial count was estimated at 30,60 and 90 days of during composition it was determined by serial dilution technique as described by Dhingra and Sinclair (1993). All the results were expressed on dry basis. Experimental data were analysed by adopting standard statistical methods of analysis of variance as given Gomez and Gomez (1984).

\section{Results and Discussion}

\section{Physico-chemical properties of compost during decomposition}

The $\mathrm{pH}$ controls microbial activity during the process of decomposition. The significant variation in $\mathrm{pH}$ (7.87 to 7.40$)$ was observed under treatments of $1.5 \%$ urea $+6 \% \mathrm{RP}+1 \%$ $\mathrm{S}$ incorporated with WS and SCS at all stages of decomposition (Table 4). The increased in $\mathrm{pH}$ with mixing of different levels of $\mathrm{RP}(6,9$ and $12 \%$ ) was observed during initial period (0 days after decomposition). The increased in $\mathrm{pH}$ with increased in levels of rock phosphate was due to presence of $\mathrm{CaCO}_{3}$ in rock phosphate however, the $\mathrm{pH}$ during subsequent period of decomposition was decline 
significantly under all treatments. The significant decreased in $\mathrm{pH}$ with increase in period of decomposition corresponding to all the treatment attributed to the liberation of various numbers of organic acids produced during the course of decomposition of organic matter. Similar dynamics of $\mathrm{pH}$ was observed by Thakur and Sharma (1998) with inoculation of Azotobacter and addition of different levels of rock phosphate during composting. The $\mathrm{pH}$ significantly decreased with increase in period of decomposition. Banta and Dev (2009) and Patra and Bandyopadhyay (2010) also reported that similar $\mathrm{pH}$ change of the compost treatment after 90 day of decomposition.

The decomposition rate of organic matter is affected by $\mathrm{C}: \mathrm{N}$ ratio of substrate which ultimately governs the release rate of organic acids, dissolution of mineral salts and nutrients as well. The same fact was observed in present study. In general, the electrical

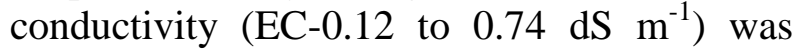
increased as the composting period progressed in WS pits under different treatments (Table 4). However, there was slight increase in the EC $\left(0.12\right.$ to $\left.0.53 \mathrm{dS} \mathrm{m}^{-1}\right)$ with the composting period progressed in SCS pits under different treatments. Rashad et al., (2010) reported the EC value $<1.5 \mathrm{dS} \mathrm{m}^{-1}$ in mature compost.

The increased in the EC with composting due to increase in the soluble saltsdue to dissolution of rock phosphate, gypsum due to action of organic acids as result of decomposition process.

\section{Organic carbon and $\mathrm{C}: \mathrm{N}$ ratio}

The organic carbon content was decreased with the increased in the days of decomposition. The significantly lowest carbon decreased was recorded under WS (47.34 to $24.48 \%$ ) as compared to SCS (52.59 to $25.43 \%$ ) (Table 5). The differential variation in rate of loss of carbon was due to differences in $\mathrm{C}: \mathrm{N}$ ratio. The microbes utilize nitrogen, phosphorus and sulphur for their rapid multiplication, this multiplication further resulted in rapid decomposition organic substrate. Similarly, with the addition of different levels of rock phosphate, urea and sulphur caused significant decline in total carbon due to rapid decomposition.

Thakur and Sharma (1998) reported that with the increased in levels of RP and time of decomposition there was decreased in organic carbon. Banta and Dev (2009) and Patara and Bandyopadhyay (2010) are also found similar result. However, in present experiment, rapid reduction in organic carbon was noticed during 60 and 90 days of decomposition. Which indicate that this period was peak period for microbial activity which ultimately leads to rapid decomposition of organic matter.

The C:N ratio at the initiation of decomposition various from 67.69-54.22, which narrowed down to 22.61-16.95 at the maturity of compost (Fig. 1). The C:N ratio was decreased with the days after decomposition, similarly it was also decline with increased in the levels of RP, gypsum along with WS and SCS.

The decreased in $\mathrm{C}$ : $\mathrm{N}$ ratio with days after decomposition was due to decreased in carbon as a result of loss of carbon through microbial oxidation. Irrespective of composting period, there was a significant effect of treatments on $\mathrm{C}: \mathrm{N}$ ratio. All the compost treatments showed decreased in $\mathrm{C}$ : $\mathrm{N}$ ratio with time of decomposition. Goyal et al., (2005), Manjunatha and Ravi (2013) and Patar and Bandyopadhyay (2010) reported the decreasing trend of $\mathrm{C}$ : $\mathrm{N}$ ratio with increased in RP level at subsequent stages of decomposition. 
Nutrient composition of compost during decomposition

\section{Total nitrogen}

The total nitrogen content in compost increased with the all the treatments and advancement of decomposition process in different pits (Table 5). Rasal et al., (1987) and Patara and Bandyodhyay (2010) were reported increased in the nitrogen content during different stages of decomposition. The total nitrogen increased with increasing levels of urea solution (1.5 to $4.5 \%$ application of urea solution) application under all pits. The significantly highest increased in the total $\mathrm{N}$ was recorded in SCS treated with $4.5 \%$ urea + $12 \% \mathrm{RP}+3 \% \mathrm{~S}$. This was due to higher content of nitrogen in SCS (0.93 to $1.50 \%)$ as compared to WS (0.69 to $1.42 \%)$. The total nitrogen content increased significantly due to the mineralization of nutrients by the microorganisms and release of nitrogen after death and decay of microbial population. The results are in close agreement with findings of Mathur et al., (1980).

Total phosphorus, water soluble phosphorus and citrate soluble phosphorus

Different levels of rock phosphate and gypsum incorporated with WS and SCS resulted in significant increase in total $\mathrm{P}$, water soluble $\mathrm{P}$ and citrate soluble $\mathrm{P}$ content of compost during subsequent stages of decomposition (Table 6). The highest significant increased in total P $(1.70 \%)$, water soluble $\mathrm{P}(0.075 \%)$ and citrate soluble $\mathrm{P}(0.94 \%)$ was recorded under SCS treated with $4.5 \%$ urea $+12 \% \mathrm{RP}+3 \% \mathrm{~S}$ followed by WS treated with $4.5 \%$ urea $+12 \%$ $\mathrm{RP}+3 \% \mathrm{~S}$ (total P-1.89\%, water soluble P$0.068 \%$ and citrate soluble P $0.95 \%$ ). The application of higher doses of RP maintained higher concentration of different $\mathrm{P}$ forms at the end of decomposition of residues. Total phosphorus, water soluble phosphorus and citrate soluble phosphorus content increased with decomposition and this increase was proportional to loss in organic matter during decomposition. Similar kind of results were also reported by Thakur and Sharma (1997) reported that the incorporation of RP to crop residues caused significant increase in the Total $\mathrm{P}$, water soluble $\mathrm{P}$ and citrate soluble $\mathrm{P}$ content with progressive period of composting, which was proportional to loss of organic matter. The organic acids, carbonic acid and chelating substances produced during decomposition help in the liberation of phosphate from rock phosphate. Khan and Joergensen (2009) reported the increased in different fraction of phosphorus in compost due to application of inorganic $\mathrm{P}$ fertilizer during composting. The composting with RP had significantly higher citrate soluble $\mathrm{P}$ compared to straw compost without RP (Biswas and Narayansamy, 2006).

\section{Total potassium}

The potassium content of compost was increased significantly with the increase in levels of RP and S (Table 7). Among the different treatments WS treated with $12 \% \mathrm{RP}$ $+3 \% \mathrm{~S}$ recorded significant improvement by $0.78 \%$ followed by SCS treated with $4.5 \%$ urea $+12 \% \mathrm{RP}+3 \% \mathrm{~S}$ by $0.66 \%$ as compare to initial (at 0 days of decomposition) of 0.61 and 0.58 respectively. Qureshi et al., (2014) also reported the increased in total potassium during composting with rock phosphate. Although the values of potassium content at final stage was higher as compare to initial stage but this increase was not spectacular. This was due to the share of organic matter percentage corresponding to different treatments was reduced automatically, which ultimately determined the percentage of total potassium in compost. Microbial population played significant role in term of total potassium percentage in the compost at all dates of decomposition. 
Table.1 Initial composition of WS and SCS

\begin{tabular}{|c|l|c|c|}
\hline Sr. No. & \multicolumn{1}{|c|}{ Parameter } & Wheat straw & Shredded Cotton stalk \\
\hline 1 & Cellulose $(\%)$ & 41.2 & 58.5 \\
\hline 2 & Hemi cellulose $(\%)$ & 32.4 & 14.4 \\
\hline 3 & Lignin $(\%)$ & 6.3 & 21.5 \\
\hline 4 & Protein $(\%)$ & 3.44 & 2.94 \\
\hline 5 & $\mathrm{~N}(\%)$ & 0.55 & 0.47 \\
\hline 6 & $\mathrm{P}(\%)$ & 0.31 & 0.10 \\
\hline 7 & $\mathrm{~K}(\%)$ & 0.54 & 0.61 \\
\hline 8 & $\mathrm{~S}(\%)$ & 0.09 & 0.04 \\
\hline 9 & $\mathrm{Zn}\left(\mathrm{mg} \mathrm{kg}^{-1}\right)$ & 11.1 & 31.5 \\
\hline 10 & $\mathrm{Fe}\left(\mathrm{mg} \mathrm{kg}^{-1}\right)$ & 110.3 & 205.4 \\
\hline 11 & $\mathrm{Mn}\left(\mathrm{mg} \mathrm{kg}^{-1}\right)$ & 13.6 & 32.4 \\
\hline 12 & $\mathrm{Cu}\left(\mathrm{mg} \mathrm{kg}^{-1}\right)$ & 8.27 & 20.47 \\
\hline
\end{tabular}

Table.2 Composition of RP

\begin{tabular}{|c|l|c|}
\hline Sr. No & \multicolumn{1}{|c|}{ Chemical composition } & Content \\
\hline 1. & Total P $(\%)$ & 7.25 \\
\hline 2. & Water soluble P $(\%)$ & 0.003 \\
\hline 3. & Citrate soluble P(\%) & 1.10 \\
\hline 4. & Potassium $(\%)$ & 0.13 \\
\hline 5. & Sulphur $(\%)$ & 0.40 \\
\hline 6. & Iron $\left(\mathrm{mg} \mathrm{kg}^{-1}\right)$ & 5870 \\
\hline 7. & Manganese $\left(\mathrm{mg} \mathrm{kg}^{-1}\right)$ & 904 \\
\hline 8. & Zinc $\left(\mathrm{mg} \mathrm{kg}^{-1}\right)$ & 213 \\
\hline 9. & Copper $\left(\mathrm{mg} \mathrm{kg}^{-1}\right)$ & 40 \\
\hline
\end{tabular}

Table.3 Composition of gypsum

\begin{tabular}{|c|l|c|}
\hline Sr. No & Chemical composition & Content \\
\hline 1 & Sulphur $(\%)$ & 14.0 \\
\hline 2 & Calcium $(\%)$ & 19.1 \\
\hline 3 & Phosphorus $\left(\mathrm{mg} \mathrm{kg}^{-1}\right)$ & 30.6 \\
\hline 4 & Manganese $\left(\mathrm{mg} \mathrm{kg}^{-1}\right)$ & 14.6 \\
\hline 5 & Zinc $\left(\mathrm{mg} \mathrm{kg}^{-1}\right)$ & 0.91 \\
\hline 6 & Copper $\left(\mathrm{mg} \mathrm{kg}^{-1}\right)$ & 1.33 \\
\hline 7 & Iron $\left(\mathrm{mg} \mathrm{kg}^{-1}\right)$ & 10.45 \\
\hline
\end{tabular}


Table.4 pH and EC during decomposition of nitro-phospho-sulpho compost

\begin{tabular}{|c|c|c|c|c|c|c|c|c|c|c|}
\hline Treatments & \multicolumn{9}{|c|}{$\mathrm{pH}$} & \multicolumn{4}{c|}{$\begin{array}{c}\mathrm{EC} \\
\left(\mathrm{dS} \mathrm{m}^{-1}\right)\end{array}$} \\
\cline { 2 - 12 } & \multicolumn{4}{|c|}{ Days after decomposition } & \multicolumn{4}{c|}{ Days after decomposition } \\
\hline & $\mathbf{0}$ & $\mathbf{3 0}$ & $\mathbf{6 0}$ & $\mathbf{9 0}$ & $\mathbf{1 2 0}$ & $\mathbf{0}$ & $\mathbf{3 0}$ & $\mathbf{6 0}$ & $\mathbf{9 0}$ & $\mathbf{1 2 0}$ \\
\hline $\mathrm{T}_{1}$ & $7.69^{\mathrm{c}}$ & $7.64^{\mathrm{d}}$ & $7.56^{\mathrm{c}}$ & $7.32^{\mathrm{f}}$ & $7.30^{\mathrm{e}}$ & $0.12^{\mathrm{a}}$ & $0.15^{\mathrm{e}}$ & $0.34^{\mathrm{e}}$ & $0.32^{\mathrm{e}}$ & $0.56^{\mathrm{c}}$ \\
\hline $\mathrm{T}_{2}$ & $7.70^{\mathrm{b}}$ & $7.69^{\mathrm{c}}$ & $7.57^{\mathrm{b}}$ & $7.37^{\mathrm{e}}$ & $7.37^{\mathrm{d}}$ & $0.14^{\mathrm{a}}$ & $0.25^{\mathrm{b}}$ & $0.41^{\mathrm{a}}$ & $0.43^{\mathrm{b}}$ & $0.66^{\mathrm{b}}$ \\
\hline $\mathrm{T}_{3}$ & $7.80^{\mathrm{ab}}$ & $7.73^{\mathrm{b}}$ & $7.62^{\mathrm{a}}$ & $7.44^{\mathrm{d}}$ & $7.42^{\mathrm{c}}$ & $0.15^{\mathrm{a}}$ & $0.29^{\mathrm{a}}$ & $0.45^{\mathrm{b}}$ & $0.47^{\mathrm{a}}$ & $0.77^{\mathrm{a}}$ \\
\hline $\mathrm{T}_{4}$ & $7.83^{\mathrm{ab}}$ & $7.79^{\mathrm{ab}}$ & $7.58^{\mathrm{ab}}$ & $7.42^{\mathrm{c}}$ & $7.42^{\mathrm{c}}$ & $0.12^{\mathrm{a}}$ & $0.20^{\mathrm{d}}$ & $0.27^{\mathrm{f}}$ & $0.27^{\mathrm{f}}$ & $0.40^{\mathrm{f}}$ \\
\hline $\mathrm{T}_{5}$ & $7.84^{\mathrm{ab}}$ & $7.81^{\mathrm{ab}}$ & $7.59^{\mathrm{ab}}$ & $7.46^{\mathrm{b}}$ & $7.43^{\mathrm{b}}$ & $0.13^{\mathrm{a}}$ & $0.23^{\mathrm{c}}$ & $0.33^{\mathrm{d}}$ & $0.32^{\mathrm{d}}$ & $0.46^{\mathrm{e}}$ \\
\hline $\mathrm{T}_{6}$ & $7.87^{\mathrm{a}}$ & $7.82^{\mathrm{a}}$ & $7.62^{\mathrm{a}}$ & $7.57^{\mathrm{a}}$ & $7.56^{\mathrm{a}}$ & $0.14^{\mathrm{a}}$ & $0.28^{\mathrm{a}}$ & $0.35^{\mathrm{c}}$ & $0.40^{\mathrm{c}}$ & $0.53^{\mathrm{d}}$ \\
\hline $\mathrm{SE}( \pm \mathrm{m})$ & 0.025 & 0.014 & 0.013 & 0.01 & 0.004 & 0.006 & 0.007 & 0.008 & 0.011 & 0.009 \\
\hline LSD at 5\% & 0.07 & 0.04 & 0.04 & 0.03 & 0.01 & 0.02 & 0.02 & 0.02 & 0.03 & 0.03 \\
\hline
\end{tabular}

Table.5 Organic carbon and Total nitrogen during decomposition of nitro-phospho-sulpho compost

\begin{tabular}{|c|c|c|c|c|c|c|c|c|c|c|}
\hline Treatments & \multicolumn{4}{|c|}{$\begin{array}{c}\text { Organic Carbon } \\
(\%)\end{array}$} & \multicolumn{5}{c|}{$\begin{array}{c}\text { Total nitrogen } \\
(\%)\end{array}$} \\
\cline { 2 - 13 } & \multicolumn{4}{|c|}{ Days after decomposition } & \multicolumn{4}{c|}{ Days after decomposition } \\
\hline & $\mathbf{0}$ & $\mathbf{3 0}$ & $\mathbf{6 0}$ & $\mathbf{9 0}$ & $\mathbf{1 2 0}$ & $\mathbf{0}$ & $\mathbf{3 0}$ & $\mathbf{6 0}$ & $\mathbf{9 0}$ & $\mathbf{1 2 0}$ \\
\hline $\mathrm{T}_{1}$ & $46.4^{\mathrm{e}}$ & $46.4^{\mathrm{d}}$ & $38.5^{\mathrm{c}}$ & $31.1^{\mathrm{a}}$ & $26.7^{\mathrm{b}}$ & $0.69^{\mathrm{e}}$ & $0.84^{\mathrm{e}}$ & $0.94^{\mathrm{e}}$ & $1.07^{\mathrm{f}}$ & $1.18^{\mathrm{e}}$ \\
\hline $\mathrm{T}_{2}$ & $47.3^{\mathrm{c}}$ & $45.5^{\mathrm{e}}$ & $37.4^{\mathrm{e}}$ & $30.4^{\mathrm{b}}$ & $25.4^{\mathrm{d}}$ & $0.79^{\mathrm{d}}$ & $0.92^{\mathrm{d}}$ & $1.12^{\mathrm{c}}$ & $1.24^{\mathrm{e}}$ & $1.34^{\mathrm{c}}$ \\
\hline $\mathrm{T}_{3}$ & $46.5^{\mathrm{d}}$ & $44.3^{\mathrm{f}}$ & $36.3^{\mathrm{f}}$ & $28.5^{\mathrm{e}}$ & $24.5^{\mathrm{e}}$ & $0.83^{\mathrm{c}}$ & $1.02^{\mathrm{b}}$ & $1.15^{\mathrm{b}}$ & $1.29^{\mathrm{c}}$ & $1.42^{\mathrm{b}}$ \\
\hline $\mathrm{T}_{4}$ & $51.4^{\mathrm{b}}$ & $51.4^{\mathrm{a}}$ & $40.3^{\mathrm{a}}$ & $30.3^{\mathrm{c}}$ & $27.9^{\mathrm{a}}$ & $0.93^{\mathrm{b}}$ & $1.01^{\mathrm{c}}$ & $1.06^{\mathrm{d}}$ & $1.23^{\mathrm{d}}$ & $1.31^{\mathrm{d}}$ \\
\hline $\mathrm{T}_{5}$ & $52.6^{\mathrm{ab}}$ & $50.7^{\mathrm{b}}$ & $39.3^{\mathrm{b}}$ & $29.6^{\mathrm{d}}$ & $26.6^{\mathrm{c}}$ & $0.95^{\mathrm{ab}}$ & $1.12^{\mathrm{ab}}$ & $1.24^{\mathrm{ab}}$ & $1.31^{\mathrm{b}}$ & $1.42^{\mathrm{b}}$ \\
\hline $\mathrm{T}_{6}$ & $52.6^{\mathrm{a}}$ & $49.7^{\mathrm{c}}$ & $38.4^{\mathrm{d}}$ & $28.5^{\mathrm{f}}$ & $25.4^{\mathrm{d}}$ & $0.97^{\mathrm{a}}$ & $1.16^{\mathrm{a}}$ & $1.28^{\mathrm{a}}$ & $1.35^{\mathrm{a}}$ & $1.50^{\mathrm{a}}$ \\
\hline $\mathrm{SE}( \pm \mathrm{m})$ & 0.16 & 0.16 & 0.14 & 0.15 & 0.18 & 0.009 & 0.017 & 0.016 & 0.009 & 0.006 \\
\hline LSD at $5 \%$ & 0.48 & 0.47 & 0.43 & 0.46 & 0.53 & 0.03 & 0.05 & 0.05 & 0.03 & 0.02 \\
\hline
\end{tabular}


Table.6 Total phosphorus during decomposition of Nitro-phospho-sulpho compost

\begin{tabular}{|c|c|c|c|c|c|c|c|c|c|c|c|c|c|c|c|}
\hline \multirow[t]{3}{*}{ Treatments } & \multicolumn{5}{|c|}{$\begin{array}{l}\text { Total Phosphorus } \\
\text { (\%) }\end{array}$} & \multicolumn{5}{|c|}{$\begin{array}{c}\text { Water Soluble P } \\
(\%)\end{array}$} & \multicolumn{5}{|c|}{$\begin{array}{c}\text { Citrate Soluble P } \\
(\%)\end{array}$} \\
\hline & \multicolumn{5}{|c|}{ Days after decomposition } & \multicolumn{5}{|c|}{ Days after decomposition } & \multicolumn{5}{|c|}{ Days after decomposition } \\
\hline & $\mathbf{0}$ & 30 & 60 & 90 & 120 & 0 & 30 & 60 & 90 & 120 & 0 & 30 & 60 & 90 & 120 \\
\hline $\mathrm{T}_{1}$ & $0.74^{\mathrm{e}}$ & $0.75^{c}$ & $1.09^{\mathrm{e}}$ & $1.38^{\mathrm{e}}$ & $1.42^{\mathrm{e}}$ & $0.023^{\mathrm{d}}$ & $0.041^{\mathrm{e}}$ & $0.048^{\mathrm{e}}$ & $0.052^{\mathrm{e}}$ & $0.059^{\mathrm{e}}$ & $0.11^{\mathrm{d}}$ & $0.37^{\mathrm{f}}$ & $0.63^{\mathrm{e}}$ & $0.76^{\mathrm{e}}$ & $0.80^{\mathrm{e}}$ \\
\hline $\mathrm{T}_{2}$ & $0.75^{\mathrm{d}}$ & $0.76^{\mathrm{b}}$ & $1.21^{\mathrm{c}}$ & $1.56^{\mathrm{c}}$ & $1.65^{\mathrm{c}}$ & $0.031^{\mathrm{b}}$ & $0.047^{\mathrm{d}}$ & $0.051^{\mathrm{d}}$ & $0.055^{\mathrm{c}}$ & $0.062^{d}$ & $0.20^{\mathrm{b}}$ & $0.48^{\mathrm{d}}$ & $0.70^{c}$ & $0.80^{c}$ & $0.86^{\mathrm{c}}$ \\
\hline $\mathrm{T}_{3}$ & $0.77^{b}$ & $0.79^{\mathrm{ab}}$ & $1.35^{\mathrm{a}}$ & $1.75^{\mathrm{a}}$ & $1.89^{\mathrm{a}}$ & $0.032^{\mathrm{ab}}$ & $0.049^{b}$ & $0.055^{\mathrm{b}}$ & $0.058^{\mathrm{b}}$ & $0.068^{\mathrm{c}}$ & $0.24^{\mathrm{a}}$ & $0.53^{b}$ & $0.73^{b}$ & $0.86^{\mathrm{ab}}$ & $0.95^{\mathrm{a}}$ \\
\hline $\mathrm{T}_{4}$ & $0.72^{\mathrm{t}}$ & $0.74^{\mathrm{d}}$ & $1.08^{\mathrm{t}}$ & $1.32^{\mathrm{t}}$ & $1.35^{\mathrm{t}}$ & $0.028^{\mathrm{c}}$ & $0.041^{\mathrm{e}}$ & $0.047^{t}$ & $0.051^{d}$ & $0.062^{d}$ & $0.11^{d}$ & $0.41^{\mathrm{e}}$ & $0.60^{\mathrm{t}}$ & $0.78^{\mathrm{d}}$ & $0.83^{\mathrm{d}}$ \\
\hline $\mathrm{T}_{5}$ & $0.76^{\mathrm{c}}$ & $0.80^{\mathrm{ab}}$ & $1.20^{\mathrm{d}}$ & $1.48^{\mathrm{d}}$ & $1.53^{d}$ & $0.031^{b}$ & $0.048^{c}$ & $0.053^{c}$ & $0.062^{\mathrm{ab}}$ & $0.070^{\mathrm{b}}$ & $0.16^{\mathrm{c}}$ & $0.50^{c}$ & $0.67^{d}$ & $0.83^{b}$ & $0.89^{b}$ \\
\hline $\mathrm{T}_{6}$ & $0.80^{\mathrm{a}}$ & $0.81^{\mathrm{a}}$ & $1.30^{\mathrm{b}}$ & $1.68^{b}$ & $1.70^{\mathrm{b}}$ & $0.034^{\mathrm{a}}$ & $0.052^{a}$ & $0.057^{\mathrm{a}}$ & $0.063^{\mathrm{a}}$ & $0.075^{\mathrm{a}}$ & $0.24^{\mathrm{a}}$ & $0.57^{\mathrm{a}}$ & $0.77^{\mathrm{a}}$ & $0.87^{\mathrm{a}}$ & $0.94^{\mathrm{ab}}$ \\
\hline $\mathrm{SE}( \pm \mathrm{m})$ & 0.007 & 0.006 & 0.006 & 0.005 & 0.005 & 0.001 & 0.001 & 0.001 & 0.001 & 0.001 & 0.008 & 0.008 & 0.008 & 0.005 & 0.007 \\
\hline LSD at $5 \%$ & 0.02 & 0.02 & 0.02 & 0.02 & 0.01 & 0.002 & 0.002 & 0.002 & 0.001 & 0.001 & 0.03 & 0.02 & 0.03 & 0.02 & 0.020 \\
\hline
\end{tabular}

Table.7 Total potassium during decomposition of nitro-phospho-sulpho compost

\begin{tabular}{|c|c|c|c|c|c|}
\hline \multirow[t]{3}{*}{ Treatments } & \multicolumn{5}{|c|}{$\begin{array}{c}\text { Total Potassium } \\
(\%)\end{array}$} \\
\hline & \multicolumn{5}{|c|}{ Days after decomposition } \\
\hline & $\mathbf{0}$ & 30 & 60 & 90 & 120 \\
\hline $\mathrm{T}_{1}$ & $0.55^{\mathrm{c}}$ & $0.63^{b}$ & $0.67^{\mathrm{c}}$ & $0.64^{c}$ & $0.69^{c}$ \\
\hline $\mathrm{T}_{2}$ & $0.58^{\mathrm{ab}}$ & $0.64^{\mathrm{ab}}$ & $0.69^{\mathrm{b}}$ & $0.72^{b}$ & $0.73^{b}$ \\
\hline $\mathrm{T}_{3}$ & $0.61^{\mathrm{a}}$ & $0.66^{\mathrm{a}}$ & $0.74^{\mathrm{a}}$ & $0.75^{\mathrm{a}}$ & $0.78^{\mathrm{a}}$ \\
\hline $\mathrm{T}_{4}$ & $0.46^{\mathrm{d}}$ & $0.53^{\mathrm{e}}$ & $0.63^{\mathrm{d}}$ & $0.55^{\mathrm{f}}$ & $0.58^{f}$ \\
\hline $\mathrm{T}_{5}$ & $0.56^{\mathrm{b}}$ & $0.57^{\mathrm{d}}$ & $0.59^{\mathrm{f}}$ & $0.60^{\mathrm{e}}$ & $0.65^{\mathrm{e}}$ \\
\hline $\mathrm{T}_{6}$ & $0.58^{\mathrm{ab}}$ & $0.58^{\mathrm{c}}$ & $0.61^{\mathrm{e}}$ & $0.63^{\mathrm{d}}$ & $0.66^{\mathrm{d}}$ \\
\hline $\mathrm{SE}( \pm \mathrm{m})$ & 0.008 & 0.005 & 0.005 & 0.006 & 0.007 \\
\hline LSD at $5 \%$ & 0.024 & 0.015 & 0.016 & 0.017 & 0.020 \\
\hline
\end{tabular}


Table.8 Sulphur and Micronutrient prepared Nitro-phospho-sulpho compost

\begin{tabular}{|c|c|c|c|c|c|}
\hline Treatment & $\begin{array}{c}\mathrm{S} \\
(\%)\end{array}$ & $\begin{array}{c}\mathrm{Zn} \\
\left(\mathrm{mg} \mathrm{kg}^{-1}\right)\end{array}$ & $\begin{array}{c}\mathrm{Fe} \\
\left(\mathrm{mg} \mathrm{kg}^{-1}\right)\end{array}$ & $\begin{array}{c}\mathrm{Mn} \\
\left(\mathrm{mg} \mathrm{kg}^{-1}\right)\end{array}$ & $\begin{array}{c}\mathrm{Cu} \\
\left(\mathrm{mg} \mathrm{kg}^{-1}\right)\end{array}$ \\
\hline $\mathrm{T}_{1}$ & $0.35^{\mathrm{f}}$ & $191.5^{\mathrm{e}}$ & $745.5^{\mathrm{e}}$ & $315.8^{\mathrm{e}}$ & $48.3^{\mathrm{e}}$ \\
\hline $\mathrm{T}_{2}$ & $0.43^{\mathrm{d}}$ & $192.8^{\mathrm{d}}$ & $747.8^{\mathrm{c}}$ & $319.0^{\mathrm{c}}$ & $51.2^{\mathrm{c}}$ \\
\hline $\mathrm{T}_{3}$ & $0.51^{\mathrm{b}}$ & $195.5^{\mathrm{b}}$ & $750.5^{\mathrm{ab}}$ & $320.3^{\mathrm{b}}$ & $52.7^{\mathrm{ab}}$ \\
\hline $\mathrm{T}_{4}$ & $0.40^{\mathrm{e}}$ & $193.5^{\mathrm{c}}$ & $746.3^{\mathrm{d}}$ & $317.5^{\mathrm{d}}$ & $50.6^{\mathrm{d}}$ \\
\hline $\mathrm{T}_{5}$ & $0.46^{\mathrm{c}}$ & $196.5^{\mathrm{ab}}$ & $748.5^{\mathrm{b}}$ & $321.3^{\mathrm{ab}}$ & $51.6^{\mathrm{b}}$ \\
\hline $\mathrm{T}_{6}$ & $0.55^{\mathrm{a}}$ & $197.5^{\mathrm{a}}$ & $751.3^{\mathrm{a}}$ & $322.3^{\mathrm{a}}$ & $53.1^{\mathrm{a}}$ \\
\hline $\mathrm{SE}( \pm \mathrm{m})$ & 0.007 & 0.664 & 0.517 & 0.500 & 0.368 \\
\hline LSD at $5 \%$ & 0.02 & 1.9 & 1.5 & 1.5 & 1.1 \\
\hline
\end{tabular}

Table.9 Microbial count during decomposition of nitro-phospho-sulpho compost

\begin{tabular}{|c|c|c|c|c|c|c|c|c|c|c|c|c|c|c|}
\hline \multirow[t]{3}{*}{$\begin{array}{c}\text { Treatme } \\
\text { nts }\end{array}$} & \multicolumn{2}{|c|}{$\begin{array}{c}\text { Bacteria } \\
\left(\mathrm{cfu} \times 10^{6} \mathrm{~g}^{-1}\right)\end{array}$} & & \multicolumn{3}{|c|}{$\begin{array}{c}\text { Fungi } \\
\left(\mathrm{cfu} \times 10^{4} \mathrm{~g}^{-1}\right)\end{array}$} & \multicolumn{3}{|c|}{$\begin{array}{l}\text { Actinomycetes } \\
\left(\mathrm{cfu} \times 10^{4} \mathrm{~g}^{-1}\right)\end{array}$} & \multicolumn{5}{|c|}{$\begin{array}{l}\text { Microbial respiration } \\
\left(\mathrm{mg} \mathrm{CO}_{2} \mathrm{~g}^{-1} 24 \mathrm{~h}^{-1}\right)\end{array}$} \\
\hline & \multicolumn{9}{|c|}{ Days after decomposition } & \multicolumn{5}{|c|}{ Days after decomposition } \\
\hline & 30 & 60 & 90 & 30 & 60 & 90 & 30 & 60 & 90 & $\mathbf{0}$ & 30 & 60 & 90 & 120 \\
\hline $\mathrm{T}_{1}$ & $24^{\mathrm{d}}$ & $39^{\mathrm{d}}$ & $33^{\mathrm{e}}$ & $24^{\mathrm{ab}}$ & $46^{\mathrm{ab}}$ & $32^{\mathrm{a}}$ & $11^{\mathrm{d}}$ & $30^{\mathrm{e}}$ & $21^{\mathrm{f}}$ & $16.53^{\mathrm{e}}$ & $36.48^{\mathrm{f}}$ & $49.18^{\mathrm{f}}$ & $32.30^{\mathrm{f}}$ & $22.63^{\mathrm{f}}$ \\
\hline $\mathrm{T}_{2}$ & $29^{b}$ & $43^{b}$ & $37^{\mathrm{b}}$ & $18^{\mathrm{c}}$ & $40^{c}$ & $29^{b}$ & $13^{b}$ & $33^{\mathrm{c}}$ & $23^{\mathrm{e}}$ & $17.58^{\mathrm{d}}$ & $39.45^{\mathrm{d}}$ & $52.38^{\mathrm{e}}$ & $34.05^{\mathrm{e}}$ & $26.28^{d}$ \\
\hline $\mathrm{T}_{3}$ & $34^{\mathrm{ab}}$ & $55^{\mathrm{a}}$ & $38^{\mathrm{a}}$ & $14^{\mathrm{e}}$ & $32^{\mathrm{e}}$ & $26^{\mathrm{e}}$ & $14^{\mathrm{ab}}$ & $38^{\mathrm{ab}}$ & $26^{b}$ & $19.40^{\mathrm{ab}}$ & $37.58^{\mathrm{e}}$ & $55.40^{\mathrm{c}}$ & $36.30^{c}$ & $27.58^{b}$ \\
\hline $\mathrm{T}_{4}$ & $28^{c}$ & $37^{\mathrm{e}}$ & $30^{f}$ & $26^{\mathrm{a}}$ & $49 a$ & $31^{\mathrm{ab}}$ & $12^{c}$ & $32^{d}$ & $24^{d}$ & $18.20^{c}$ & $41.13^{b}$ & $54.58^{d}$ & $35.93^{d}$ & $24.25^{\mathrm{e}}$ \\
\hline $\mathrm{T}_{5}$ & $28^{c}$ & $39^{d}$ & $34^{d}$ & $21^{\mathrm{b}}$ & $41^{b}$ & $28^{c}$ & $13^{\mathrm{ab}}$ & $34^{\mathrm{b}}$ & $25^{c}$ & $18.85^{b}$ & $39.58^{c}$ & $56.18^{b}$ & $36.88^{b}$ & $26.85^{\mathrm{c}}$ \\
\hline $\mathrm{T}_{6}$ & $35^{\mathrm{a}}$ & $40^{c}$ & $36^{\mathrm{c}}$ & $18^{\mathrm{d}}$ & $34^{\mathrm{d}}$ & $27^{\mathrm{d}}$ & $15^{\mathrm{a}}$ & $39^{a}$ & $29^{a}$ & $19.63^{a}$ & $42.45^{\mathrm{a}}$ & $58.38^{\mathrm{a}}$ & $39.43^{a}$ & $28.43^{a}$ \\
\hline $\mathrm{SE}( \pm \mathrm{m})$ & 0.48 & 0.54 & 0.43 & 0.64 & 0.66 & 0.53 & 0.61 & 0.71 & 0.68 & 0.108 & 0.143 & 0.142 & 0.220 & 0.113 \\
\hline $\begin{array}{l}\text { LSD at } \\
5 \%\end{array}$ & 1.4 & 1.6 & 1.3 & 2.0 & 3.0 & 2.0 & 2.0 & 2.0 & 2.0 & 0.32 & 0.43 & 0.42 & 0.66 & 0.34 \\
\hline
\end{tabular}

Fig.1 Effect of different nutrient treatments on $\mathrm{C}: \mathrm{N}$ ratio of compost

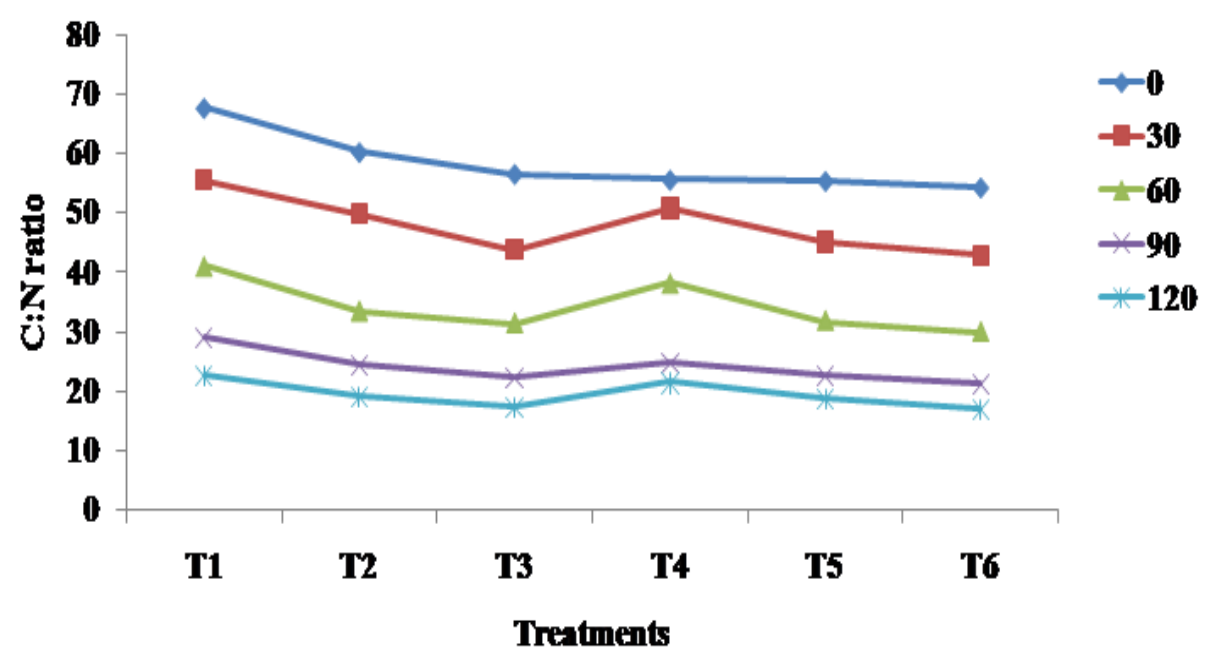

Fig 1: Effect of different nutrient treatments on C:N ratio of compost 
Potassium content increased with the progressive increased in decomposition of organic matter in the compost.

\section{Sulphur and micronutrient}

The sulphur content was increased with the increased in the levels of sulphur (through gypsum) and RP. However, the compost prepared from WS and SCS with $4.5 \%$ urea + $12 \% \mathrm{RP}+3 \%$ Sand recorded significantly highest sulphur content (0.35 to $0.55 \%)$. Relatively lower sulphur was recorded with lower levels of rock phosphate and gypsum (Table 8). Higher S contents were recorded at 120 day of composting. The increased in sulphur content was due to gypsum mineralization progressive process by various microbial population activity (Ammal et al., 2001 and Ntekim, 2009). Chari and Ravi (2013) reported increased in sulphur in cotton stalk compost due to composting with urea and single super phosphate

The micronutrients contents of compost followed similar trend as sulphur. Different levels of rock phosphate and gypsum are incorporated with crop residues resulted significant increase in micronutrients of prepared compost. The micronutrients contents (Zn $197.5 \mathrm{mg} \mathrm{kg}^{-1}$, Fe $751.3 \mathrm{mg} \mathrm{kg}^{-1}$, Mn $322.3 \mathrm{mg} \mathrm{kg}^{-1}$ and $\mathrm{Cu} 53.1 \mathrm{mg} \mathrm{kg}^{-1}$ )of prepared compost was significantly highest, where 4.5 urea $+12 \% \mathrm{RP}+3 \% \mathrm{~S}$ was incorporated with WS and SCS while, lowest micronutrients contents (Zn $191.5 \mathrm{mg} \mathrm{kg}^{-1}, \mathrm{Fe}$ $745.5 \mathrm{mg} \mathrm{kg}^{-1}$, Mn $315.8 \mathrm{mg} \mathrm{kg}^{-1}$ and $\mathrm{Cu} 48.3$ $\mathrm{mg} \mathrm{kg}^{-1}$ ) were recorded under WS and SCS with $6 \% \mathrm{RP}+1 \% \mathrm{~S}$.

Muhammad et al., (2010) reported composting municipal solid waste with RP $5 \%, \mathrm{FeSO}_{4} 1 \%$, and lime 0.63 recorded significant changes in water-soluble metals $(\mathrm{Zn}, \mathrm{Mn}$ and $\mathrm{Cu}$ ) at the end stage of the decomposition.

\section{Microbial population (Bacteria, Fungi and Actinomycetes)}

The significantly highest microbial population recorded in WS crop residues treated with $4.5 \%$ urea $+12 \% \mathrm{RP}+3 \%$ sulphur favored the growth of bacteria $\left(55 \times 10^{6} \mathrm{~g}^{-1}\right)$ and actinomycetes $\left(39 \times 10^{4} \mathrm{~g}^{-1}\right)$, whereas fungal count $\left(49 \times 10^{4} \mathrm{~g}^{-1}\right)$ was maximum under SCS treated with $1.5 \%$ urea $+6 \% \mathrm{RP}+1 \%$ Safter 60 days of decomposition (Table 9). In the subsequent stages of composting, the microbial count was narrowed down. The high temperature in the composting system might have destroyed the microbial population. In the initial stages of composting the microbial population was comparatively lower than succeeding stages of composting. The mesophyllic organisms initiated the process of composting; this might be reason for non-proliferation of microbial count as results of high temperature at subsequent stages of composting destroyed the bacterium and microbial population. Gogoi et al., (2013) and studied decomposing rice straw incorporation with rock phosphate caused significant increase microbial population.

\section{Microbial respiration}

The microbial respiration is an important feature that determines compost quality and relates to the degree to which the rate of microbial activity and organic matter has been stabilized. The microbial respiration was increased during initial phase of decomposition up to 60 days, thereafter the microbial respiration was found to be decreased with concomitant decreased in microbial population and increase in maturity of compost (Table 9). Bernal et al., (1988) and Ajwa and Tabatabai (1994) reported that the carbon mineralization decreased as the composting time lengthened. Gogoi et al., (2013) and Goyal et al., (2005) found that microbial inoculants and RP significantly 
increased microbial respiration during decomposition stages. The lowest values of $\mathrm{C}$ mineralization were found for the mature samples, and only compost which had not attained an advanced degree of maturation. For instance the highest microbial respiration was observed in SCS treated with $4.5 \%$ urea + $12 \% \mathrm{RP}+3 \% \mathrm{~S}$ followed by WS treated with $4.5 \%$ urea $+12 \% \mathrm{RP}+3 \% \mathrm{~S}$ at 60 days of decomposition. This was because of the presence of a high concentration of easily degradable organic carbon in the wastes, which led to a large growth in the microbial population which was reflected in earlier data with respect to microbial population. After the initially high mineralization rate there was a gradual decrease in all treatments before it became fairly constant.

\section{Acknowledgements}

The authors are sincerely thankful to Prof. D.B. Tamgadge, Head, Department of Soil Science and Agricultural Chemistry, Dr. Panjabrao Deshmukh Krishi Vidyapeeth, Akola, Maharashtra, for providing all the facilities for my M.Sc. research.

\section{Abbreviations}

WS, wheat straw; SCS, shredded cotton stalk; $\mathrm{EC}$, electrical conductivity; $\mathrm{C}: \mathrm{N}$ ratio, carbon:Nitrogen ratio;

\section{References}

Ajwa H.A. and Tabatabai M.A. (1994). Decomposition of different organic materials in soils. Biol. Fertil. Soils 18, 175-182.

Ammal U.B., Mathan K.K. and Mahimraja S. (2001). Effect of different levels of rock phosphate sulphur granule on yield and nutrient availability. Indian J. Agric. Res. 35(3), 166-170.

Banta G. and Dev S.P.(2009). Field evaluation of nitrogen enriched phosphocompost prepared from green biomass of Lantana camara in wheat. Indian J. Ecol. 36(1), 39-44.

Bernal M.P., Sanchez-Monedero M.A., Paredes C., Roig A. (1998) With carbon mineralization from organic wastes at different composting stages during their incubation soil. Agri. Ecosys. Env. 69, 175-189.

Biswas D.R. and Narayansamy G. (2006). Rock phosphate enriched compost: An approach to improve low-grade Indian rock phosphate. Bioresource Technology, 97, 2243-2251.

Chari M. and Ravi M.V. (2013). Evaluation of Quality and Nutrient Status of Enriched Compost. J. of Agri. Vet. Sci. 6(2), 19-23.

Chesnin L. and Yien C.H.(1950). Turbidimetric determination of available sulphur. Soil Sci. Am. Proc. $15,149-151$.

Dhingra D.A. and Sinclair J.B.(1993) Basic plant pathology Method, CRC, Lewis Pub. London, UK, pp.179-180.

Gogoi D., Nath D.J. and Borah D.K. (2013). Augmentation of the fertilizer values of compost through beneficial microbes amid rock phosphate amendment during curing stage. Indian J. Agric. Res., 47 (4): $304-310$.

Gomez K.A. and Gomez A.A. (1984). Statistical Procedure for Agricultural Research. John Wiley and Sons, New York, pp 241-266.

Goyal S., Dhull S.K. and Kapoor K.K. (2005). Chemical and biological changes during composting of different organic wastes and assessment of compost maturity. Bioresour. Tech., 96, 1584-1591.

Jackson M.L. (1973). Soil chemical analysis (Edn. 2) Prentice Hall of India Pvt. Ltd., New Delhi, pp 69-182.

Khan, K.S., Joergensen, R.G. (2009). 
Changes in microbial biomass and $\mathrm{P}$ fractions in biogenic household waste compost amended with inorganic $\mathrm{P}$ fertilizers. Biores. Technol. 100, 303309.

Manjunatha, C.K., Ravi, M. V.(2013). Evaluation of quality and nutrient status of enriched compost. J. of Agri. Vet. Sci. 6(2), 19-23.

Muhammad K.I., Tahira S., AnwarH., Khurshed A.(2010). Effect of enrichment on chemical properties of MSW compost. Bioresour. Tech. 10, 5969-5977.

Ntekim, E.E.(2009). Impact of geological variables on gypsum mineralisation: assessment of the guyuk gypsum occurrences, N. E. Nigeria. Continental J. Earth Sci. 4,12-22.

Page, A.L.(1982). Methods of Soil AnalysisPart II, Chemical and Microbiological Properties, Am. Soc. Agron. Inc. \& Soil Sci. Soc. Am. Inc, Madison Wisconsin, USA.

Pandey A., Biswas S., Sukumaran R.K. and Kaushik N. (2009). Study on Availability of Indian Biomass Resources for Exploitation: A Report Based on a Nationwide Survey TIFAC, New Delhi.

Parr, J.F., Papendick, R.I., and Colacicco, D. (1986). Recycling of organic wastes for a sustainable agriculture. In: LopezReal, J.M. and R.D. Hodges (eds.), pp. 29-43, Biol. Agri. Horti. 3, 115-130.

Patra S. and Bandyopadhyay S.(2010).
Preparation of phosphorus enriched compost: Effect of rock phosphate and microbial inoculums. Green Farming, 1(6), 580-583.

Qureshi S. A., Rajput A., Memon M. and. Solangi M. A. (2014). Nutrient composition of rock phosphate enriched compost from various organic wastes. $J$. of Scientific Res. 2(3), 047-051.

Rasal P. H., Kalbhor H.B., Shingte V.V. and Patil P.L. (1987). Enrichment of city compost. J. Indian Soc. Soil Sci., 35, 311-312.

Rashad F.M., Walid D.S. and Mohamed A.M.(2010). Bioconversion of rice straw and certain agro-industrial wastes to amendments for organic farming systems: Composting, quality, stability and maturity indices. Bioresour. Tech. 101, 5952-5960

Reddy T.Y. and Reddy G.H.S. (2002). Principles of Agronomy, Kalyani Pub. New Delhi, 22-28.

Sibi G.(2007). Role of phosphate solubilizing fungi during phosphocompost production and their effect on the growth of tomato (Lycopersicon esculentum L) plants. J. Applied Natu. Sci., 3(2), 287-290.

Thakur S.K. and Sharma C.R.(1998). Effect of rock phosphate enrichment and Azotobacter inoculation on the transformation of nitrogen and phosphorus during composting. $J$. Indian Soc. Soil Sci., 46(2), 228-231.

\section{How to cite this article:}

Kaushal Kumar, D.V. Mali, A.O. Shirale, S.D. Jadhao, V.K. Kharche, A.N. Paslawar, Sanjay Kumar and Shrimohan Meena. 2018. Integrated Use of Different Sources of Nutrients and Microbes for Improving Quality of Enrich Compost. Int.J.Curr.Microbiol.App.Sci. 7(12): 1950-1961. doi: https://doi.org/10.20546/ijcmas.2018.712.225 